\title{
Functional Morphometric Research on Blood Regulating Organs in Animal Models with Special Emphasis on Cardiovascular Conditions: A Review
}

\author{
Anas $\mathrm{SQ}^{1 *}$, Muhammad SK${ }^{2}$, Muhmmad GS33, Yusuf A2, Konto M2, Muqadar \\ $\mathrm{S}^{4}$ and Khan $\mathrm{SA}^{5}$ \\ ${ }^{1}$ Department of Anatomy, University of Agriculture, Faisalabad, Pakistan \\ ${ }^{2}$ Faculty of Veterinary Medicine, University, Putra, Malaysia \\ ${ }^{4}$ Department of Anatomy and Histology, Agricultural University, Peshawar, KPK, Pakistan \\ 5Department of Livestock and Dairy Development KPK, Pakistan
}

Review Article

Volume 1 Issue 1

Received Date: January 06, 2017

Published Date: January 20, 2017

*Corresponding author: Anas Sarwar Qureshi Professor/Chairman, Department of Anatomy, University of Agriculture, Faisalabad - Pakistan, Tel: +92041 9200161-70/3102; E-mail: anas-sarwar@uaf.edu.pk

\begin{abstract}
Cardiovascular diseases (CVDs) have become the number one killer in the world and more people die annually from CVDs than from any other cause. Since the etiology and pathogenesis of cardiovascular diseases are not yet fully understood, extensive research work has been carried out to improve the basic information on the morphology and histology in different species during past few decades. Since late 1970s focus of research shifted to bovine species. These studies were complemented by the morphology of inner organs of laboratory and wild animals. Parallel, the correlation between the morphological and histological parameters in health and disease conditions was recorded. There are some correlations between some connective tissue parameters, which establish a morpho physiological relation with the three organs which are important for the regulation of the cardiovascular system namely heart, kidney and adrenal gland. This reviews is an attempt to compile scattered information on structural morphology of the blood pressure regulating organs in domestic species and to determine their role in exploring anatomic-pathological cardiovascular.
\end{abstract}

Keywords: Age; Sex; Anatomical; Histological; Blood Pressure; Animal Models

\section{Introduction}

Cardiovascular diseases (CVDs) are a group of disorders of the heart and blood vessels. According to an estimate 17.5 million people died from CVDs in 2012, representing $31 \%$ of all global deaths. Of these deaths, an estimated 7.4 million were due to coronary heart disease [1-4]. Out of the 16 million deaths under the age of 70 due to non-communicable diseases, $82 \%$ are in low and middle income countries and $37 \%$ are caused by CVDs [5].

Functional Morphometric Research on Blood Regulating Organs in 
The occurrence of coronary heart disease is strictly related to the blood pressure level, specifically systolic type of blood pressure. The increase in pulse pressure is a predictive factor of coronary mortality as heart diseases [6]. The relationship between blood pressure level and coronary heart disease seems to be linear, continuous and independent.

Quantitative morphological data on the blood pressure and blood volume related organs i.e., heart, kidney and adrenal glands is assumed critical for the better understanding of etiology and pathogenesis of heart related diseases. These organs are closely related to blood pressure regulations in which are interconnected through renin-angiontensin-aldosterone system (RAAS). The renin-angiotensin-aldosterone system (RAAS) is a major endocrine/paracrine system that regulates blood pressure via angiotensin release and fluid and electrolyte homoeostasis via aldosterone release $[7,8]$. Recently it was discovered that local synthesis of all the RAAS components occurs in target organs and their tissues (the heart, kidneys, vessels, brain tissues) [9]. Role of zona glomerulosa through elevated concentrations of aldosterone are associated with several cardiovascular diseases [10] and have been shown to elevate blood pressure, cause left ventricular hypertrophy, and promote cardiac fibrosis [11].

For a thorough comprehension of the anatomy and physiology of the cardiovascular system, several studies have been undertaken on the morphological and histological aspects in various livestock species found in western countries [4,12-14] Continuing to this effort we have carried out some research work in indigenous species in subcontinent, ie., buffaloe, camel, goat and sheep [15-21]. Results of these studies are reviewed in this paper.

\section{Heart}

\section{Macroscopic Parameters of Heart}

Comparison of various heart shapes of domestic animals (Table 1) revealed that the shape of heart in all species is cone like, with minor differences [22]. In some breeds, the heart is relatively long and narrow and in others much wider and shorter. In the absence of absolute criteria, the isolated sheep heart is most easily identified by the quality of fat [23]. These studies were endorsed by another research that the shape of the heart of goat as cone like and the coronary groove was filled with fat. Similarly, heart of red kangaroos was compared with that of placental goats, due to similar body size. The hearts of red kangaroos were relatively much larger than those of goats. Although, those of goats were 1.5 times heavier, female red kangaroos had significantly larger hearts [24]. In relation to the mass of the body, the hearts of kangaroos were more than double the mass of goats. However, although the kangaroo and goat hearts differed somewhat in shape, they did not differ in basic structure, in that the relative proportions of the major regions were similar. Erickson et al. [25], also found that the heart of domestic animals is generally cone-shaped hollow, muscular structure. Its base is directed upward (dorsal) and forwards (cranial).

\begin{tabular}{|c|c|c|c|c|c|c|c|c|c|c|}
\hline Shape & $\begin{array}{l}\text { Strongly } \\
\text { conical } \\
\text { and } \\
\text { pointed }\end{array}$ & $\begin{array}{c}\text { Relatively } \\
\text { longer } \\
\text { and } \\
\text { shorter } \\
\text { base* }\end{array}$ & $\begin{array}{l}\text { Cone and } \\
\text { pointed } \\
\text { ventral } \\
\text { part }\end{array}$ & $\begin{array}{l}\text { Irregularly } \\
\text { flattened } \\
\text { cone } \\
\text { shaped }\end{array}$ & $\begin{array}{c}\text { Laterally } \\
\text { squeezed } \\
\text { cone } \\
\text { which is } \\
\text { strongly } \\
\text { tapered } \\
\text { with } \\
\text { caudally } \\
\text { concave } \\
\text { edge }\end{array}$ & $\begin{array}{c}\text { Apex } \\
\text { more or } \\
\text { less } \\
\text { pointed* }\end{array}$ & $\begin{array}{l}\text { Conically } \\
\text { pointed* }\end{array}$ & $\begin{array}{l}\text { Whitish } \\
\text { with } \\
\text { round } \\
\text { blunt } \\
\text { apex* }\end{array}$ & & \\
\hline $\begin{array}{c}\text { Absolute } \\
\text { weight (Kg) }\end{array}$ & $0.96-1.7$ & $2.23^{*}$ & 2.56 & 3.4 & 0.185 & $\begin{array}{c}0.22 \text { to } \\
0.24\end{array}$ & $\begin{array}{l}0.072- \\
0.077^{*}\end{array}$ & $\begin{array}{l}0.03- \\
0.45^{*}\end{array}$ & $13.8 \mathrm{~g}$ & $7.5 \mathrm{~g}$ \\
\hline $\begin{array}{c}\text { Relative } \\
\text { weight (\%) }\end{array}$ & & $0.4-0.5$ & 0.4 & $0.6-0.7$ & 1.468 & 0.4 & $\begin{array}{l}0.42- \\
0.46^{*}\end{array}$ & $0.8-1.4^{*}$ & $\begin{array}{l}0.44- \\
0.55^{*}\end{array}$ & $\begin{array}{l}0.25- \\
0.47\end{array}$ \\
\hline
\end{tabular}




\begin{tabular}{|c|c|c|c|c|c|c|c|c|c|c|}
\hline & RV & & 2.86 & 2.14 & & & & & & \\
\hline $\begin{array}{l}\text { Diameter } \\
\text { of nuclei of } \\
\text { diff. } \\
\text { chambers } \\
\text { of heart }\end{array}$ & RA & 7.91 & & & & - & & & & \\
\hline & LA & 7.5 & & & & & 9.08 & & & \\
\hline & $\mathrm{RV}$ & 8.18 & & & & & 11.41 & & & \\
\hline & $\mathrm{LV}$ & 7.54 & & & & & 11.32 & & & \\
\hline $\begin{array}{l}\text { Volume of } \\
\text { nuclei of } \\
\text { different } \\
\text { chambers } \\
\text { of heart }\end{array}$ & RA & & 122 & & & & & & & \\
\hline \multirow{5}{*}{$\begin{array}{c}\text { CT Content } \\
\%\end{array}$} & LA & & 114.77 & & & 77.74 & 73.95 & & & \\
\hline & LA & & 1.75 & & & 2.76 & & & & \\
\hline & RA & & 2.14 & 5.64 & & 1.566 & 6.21 & 5.51 & 0.67 & 1.4 \\
\hline & LV & & 2.2 & 1.88 & & 2.22 & 7 & 5.79 & 1.3 & 2.4 \\
\hline & $\mathrm{RV}$ & & 2.86 & 2.14 & & & & & & \\
\hline $\begin{array}{c}\text { Diameter } \\
\text { of nuclei of } \\
\text { diff. } \\
\text { chambers } \\
\text { of heart }\end{array}$ & RA & 7.91 & & & & - & & & & \\
\hline References & $\begin{array}{c}\text { Rehan } \\
\text { and } \\
\text { Qureshi, } \\
2006 ; \\
2007\end{array}$ & $\begin{array}{c}\text { May, } \\
1970^{*} \\
\text { Spieler, } \\
1995^{* *}\end{array}$ & $\begin{array}{l}\text { Panhwar } \\
\text { et al. } \\
2004[26]\end{array}$ & $\begin{array}{c}\text { May, } 1970 \\
{[27]}\end{array}$ & $\begin{array}{c}\text { Genschow, } \\
1997 .\end{array}$ & $\begin{array}{l}\text { May, } \\
1970\end{array}$ & $\begin{array}{c}\text { Shah et } \\
\text { al., } \\
2009^{*} \\
\text { Qureshi } \\
\text { et al. } \\
2013\end{array}$ & May,1970* & $\begin{array}{c}\text { Koch } \\
\text { and } \\
\text { Berg, } \\
1985^{*}\end{array}$ & $\begin{array}{l}\text { Nietz, } \\
1997\end{array}$ \\
\hline
\end{tabular}

Table1: Macroscopic and microscopic parameters of heart in different species.

Smollich, 1995 [28] studied the macro anatomy of the heart through the measurements of individual walls of ventricles and atriums of the heart of healthy dairy cows aged: 2-8.5 years. The thickness of the left and right ventricles of the heart of cows was 30.1 to $44.1 \mathrm{~mm}$ and 15.4 to $21.6 \mathrm{~mm}$, respectively. Another report on the anatomy of the camel heart revealed that the trunk of the atrioventricular bundle was a direct continuation of the atrioventricular node with no sharp line of demarcation between the node and the bundle [29]. Generally, in all species, the absolute heart weight increases with rising age and increasing body weight. This notion was also endorsed with the observations in pigs [30]. Absolute and relative heart weight in some domestic animals is shown in Table 1. It may clearly be noted that the horse has the highest absolute heart weight, yet the relative weight is considerably higher in dogs. Relative weight of the heart in various species i.e. dogs, horses, ruminants, pigs was found to be $1 \%, 1 \%, 0.5 \%, 0.25 \%$ of body weight, respectively. Obviously, these figures will vary according to the fitness or fatness of the individual, cardiac hypertrophy (enlargement) is seen in fit animals, also in certain disease conditions resulting in an increased workload on the heart.

The sex differences in absolute and relative heart weights are also reported among other animal species in literature and it was observed two different sex populations in gray hounds in which the higher female relative heart weight was reported in animals with a better condition [31]. The relative heart weight (\%) of cattle and goats have shown that the relative weight of goats decreases up to 1-year of age and then slightly increases, also the relative weight of animals leading to active life is more than that of sluggish animals as shown in Table 4 and also relative heart weight (\%) of domestic species is given in Table 1 .

Much variation has been reported in literature regarding the relative heart weight among various 
species, mostly, the relative heart weight reduces with advancing age. A study on buffaloes reported the mean values of heart's width, circumference, and thickness of wall of right and left atria, right and left ventricles which were significantly higher in adult buffaloes than young ones. The average relative heart weight was however, significantly higher in young buffaloes when compared to the adult ones.. Absolute and relative weights of the heart, volume, length, circumference, right atrial and right ventricle wall thickness were higher in old than in kids or adult animals. He further elaborated that none of the anatomical parameters of the heart varied between male and female goats.

\section{Microscopic Parameters of Heart}

Despite gross morphological studies different scientists were also busy in observing different histological features to provide strong basis in the functional morphometric research. It was observed that three regions of the heart of goat (the sarcolemma of Purkinje cells i.e. intercalated disk, internal and surface sarcolemmal portion) showed specific characteristics. The surface density of both sarcoplasmic reticulum dyads and intercellular junction were estimated in these three sarcolemmal portions. Dyads occupy 8,1 and $0.3 \%$. The area of internal sarcolema, intercalated disk was $17 \%$ and $5 \%$ of intercalated disk and internal sarcolemma [32].

Quantitative analysis of microscopic parameters of heart include intramural connective tissue content of different chambers of heart, mean diameter and mean nd the volume of the cardiomyocytesin different chambers of heart. The holstien-frisian bulls showed in the right atrium-wall a larger nucleus volume, whereas heifers exhibit a significant greater intramyocardial connective tissue [33].
Mean diameters and volumes of nuclei of cardiomyocytes of atria and ventricles in rabbits were not different with respect to age and sex. Mean intramural connective tissue percentage of atria and ventricles are in general, conformation among domestic animals in different age groups including kids, adults and old groups of teddy goats [34]. Has established that the relative high connective tissue content of heart atria relates with their passive function as pumping organ. However, the stronger vascularisation and connective tissue distribution contributes towards the elastically which is advantageous for heart performance.

\section{He Kidneys}

\section{Macroscopic Parameters of Kidneys}

It had been found that the kidneys of the domestic species have a variety of shapes (Table 2). The kidneys of small ruminants were very different from the kidneys of the large ruminants [35]. The kidney has one lobe developed from a number of lobes. In the large ruminants the kidney had distinct lobes separated by interlobar fissures, as deep as up to the renal pyramids. In other words the fissure separated only the cortex of the kidney. The longitudinal section of the bovine kidney composed of two major calices and a multitude of minor calices. Similar results have been observed by Dyce et al. [36] in small ruminants and he expressed that the kidneys of sheep and goat were quite unlike those of cattle but conform closely in external appearance and internal structure to those of dog. They were more regular in shape than dog. Morphometric data of various species presented in Table 2 .

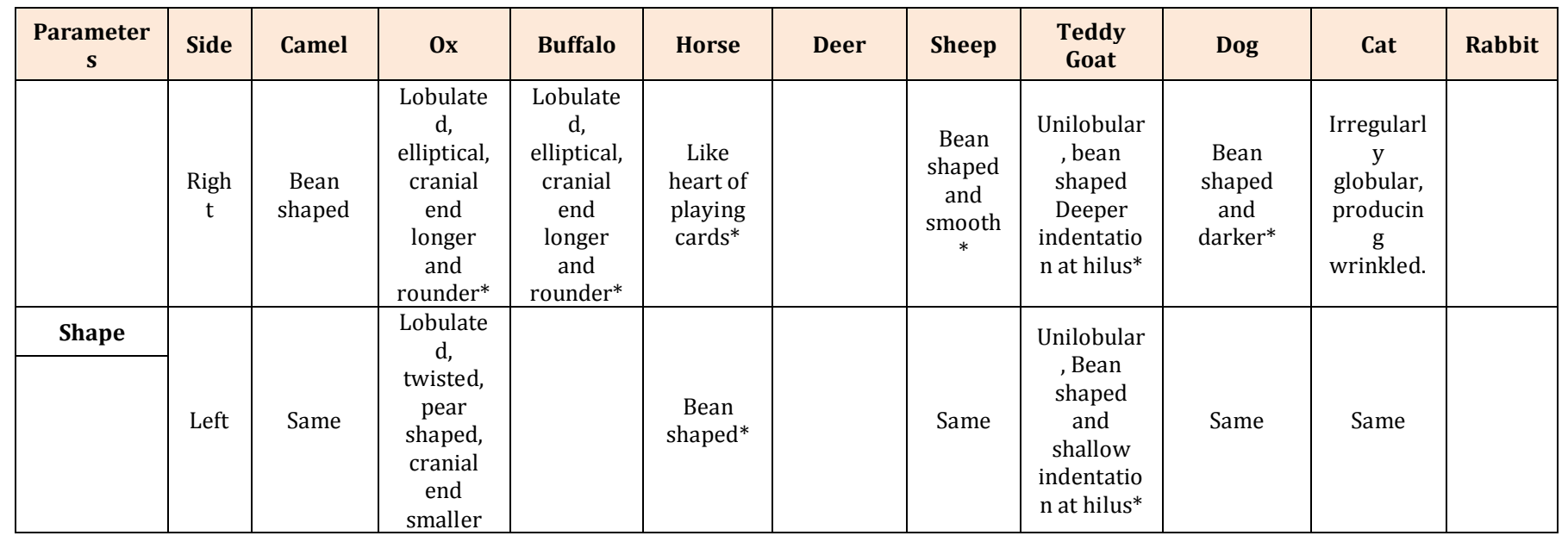




\begin{tabular}{|c|c|c|c|c|c|c|c|c|c|c|c|}
\hline \multirow{2}{*}{$\begin{array}{l}\text { Absolute } \\
\text { weight } \\
\text { (Kg) }\end{array}$} & $\begin{array}{c}\text { Righ } \\
\mathrm{t}\end{array}$ & $0.7-1$ & $0.70^{*}$ & $\begin{array}{c}0.474- \\
0.773 \\
\end{array}$ & $0.7^{*}$ & 0.097 & $\begin{array}{l}0.09- \\
0.15^{*}\end{array}$ & $\begin{array}{l}0.030- \\
0.034^{*}\end{array}$ & $0.057^{*}$ & & $5.83 \mathrm{~g}$ \\
\hline & Left & Same & $0.65^{*}$ & $583-854^{*}$ & 0.68 & 70.625 & Same & $\begin{array}{l}0.029- \\
0.034^{*}\end{array}$ & & & $5.84 \mathrm{~g}$ \\
\hline $\begin{array}{c}\text { Relative } \\
\text { weight (\%) }\end{array}$ & & & $\begin{array}{c}0.22- \\
1.24^{* *}\end{array}$ & $\begin{array}{c}0.21- \\
0.214^{* *} \\
\end{array}$ & $\begin{array}{c}0.27- \\
0.28^{* * *} \\
\end{array}$ & & $\begin{array}{c}0.21- \\
0.23^{* *}\end{array}$ & $0.17-0.19^{*}$ & & & 0.32 \\
\hline $\begin{array}{c}\text { No. of } \\
\text { glomeruli } \\
\text { per kidney } \\
(\mathrm{m})\end{array}$ & & & $4.025^{* *}$ & & & & $\begin{array}{c}0.45- \\
0.65^{* *}\end{array}$ & & $0.45^{* *}$ & & \\
\hline \multirow{2}{*}{$\begin{array}{c}\text { Volumes of } \\
\text { sub- } \\
\text { capsular } \\
\text { glomeruli }\end{array}$} & & & 81.7 & & & \multirow[b]{2}{*}{120.65} & & & & & \multirow[b]{2}{*}{211} \\
\hline & & & 88.4 & & & & & & & & \\
\hline $\begin{array}{c}\text { Area of } \\
\text { Sub- } \\
\text { capsular } \\
\text { glomeruli }\end{array}$ & Cort & & 9751 & & & \multirow[t]{2}{*}{5.194} & 11002 & & & & \multirow[t]{2}{*}{$\begin{array}{c}5168.6 \\
5\end{array}$} \\
\hline $\begin{array}{c}\text { Diameters } \\
\text { of JG }\end{array}$ & Juxt & & 8387 & & & & 12584 & & & & \\
\hline & & & & & & 102.85 & & & & & \\
\hline \multicolumn{12}{|l|}{$\begin{array}{c}\text { Volumes of } \\
\text { JG }\end{array}$} \\
\hline $\begin{array}{c}\text { Diameters } \\
\text { of JG }\end{array}$ & & & & & & 80.62 & & & & & \\
\hline References & & $\begin{array}{c}\text { Zguigal } \\
\text { and } \\
\text { Ouhsine, } \\
2004,[37 \\
\text { ] Rehan } \\
\& \\
\text { Qureshi, } \\
2006 ; \\
2007\end{array}$ & $\begin{array}{c}\text { May, } \\
1970 \text { ) } \\
\text { Mbassa, } \\
\text { 1988[38] } \\
\text { Koch and } \\
\text { Berg, } \\
1990\end{array}$ & $\begin{array}{l}\text { *(Qureshi } \\
\text { and } \\
\text { Hussain, } \\
\text { 2007) } \\
\text { Hussain } \\
\text { and } \\
\text { Qureshi, } \\
2007^{* *}\end{array}$ & $\begin{array}{c}\text { May, } \\
\text { 1970; } \\
\text { Beeuwke } \\
\text { s et al., } \\
\text { 1975[39] } \\
\text { (Newbol } \\
\text { d et al., } \\
\text { 1992) } \\
* * *\end{array}$ & $\begin{array}{l}\text { Genscho } \\
\text { w, } 1997\end{array}$ & $\begin{array}{c}\text { May, } \\
1970 * \\
\text { Koch \& } \\
\text { Berg } \\
1990^{* *} \\
\text { Schiling } \\
(1951)\end{array}$ & $\begin{array}{l}\text { Shah et al., } \\
2009^{*} \\
\text { Qureshi et } \\
\text { al., 2013** }\end{array}$ & $\begin{array}{c}\text { May, } \\
1970^{*} \\
\text { Eisenbran } \\
\text { dt \& } \\
\text { Phemister } \\
\text { 1979) }\end{array}$ & $\begin{array}{c}\text { Beeuskes } \\
\text { et al., } \\
1975\end{array}$ & $\begin{array}{l}\text { Nietz, } \\
1997\end{array}$ \\
\hline
\end{tabular}

Table2: Macroscopic and microscopic parameters of Kidneys in different species.

\section{Microscopic Parameters of the Kidneys}

Comparative study on kidneys of Bos taurus cattle and kidneys of year old Bos indicus (Zebu cattle) of East African Shorthorn breeds, reported that kidneys are divided by lobe after fixation. The cortex and medulla with subunits were measured and compared in the two sub-species [38]. These findings are in line with who stated that the bovine kidney has the most distinct lobed arrangement with external demarcation of the cortex and segmentation of the medulla into pyramids. The bases of the pyramids are adjacent to the cortex, and their apexes or papillae point toward the hilus. Thus, the ox has obvious multilobed kidneys while sheep and goat have unilobar kidneys.

Histologically peripolar cells were the glomerular epithelial cells situated within Bowman's capsule at its vascular pole. They were the largest and most abundant in sheep and goat [40].
The study reported that the width was significantly broader in Bos taurus whereas outer inner zone was significantly broader in Bos indicus. The width of the entire medulla was greater in Bos Taurus [38]. He further described that peripolar cells contained intra-cytoplasmic electron-dense membrane-bounded granules-200-2800 $\mathrm{nm}$ in diameter in the hartebeests, $200-1,740 \mathrm{~nm}$ in the impalas, $150-950 \mathrm{~nm}$ in the waterbuck and $200-2,140 \mathrm{~nm}$ in the goats [38].

\section{Adrenal Glands}

\section{Macroscopic Parameters of adrenal glands}

There are certain differences in the sizes and shapes of the adrenal glands in different animal species, as in sheep are bean shaped the right one lied to the cranial part of the medial border of right kidney. The left adrenal was usually longer and flatter than right adrenal and somewhat bent. 


\begin{tabular}{|c|c|c|c|c|c|c|c|c|c|c|c|}
\hline Parameters & & Camel & $0 x$ & Buffalo & Sheep & Deer & Horse & Teddy Goat & Dog & Cat & Rabbit \\
\hline \multirow[t]{2}{*}{ Shape } & Right & & $\begin{array}{c}\text { V- } \\
\text { shaped* }\end{array}$ & $\begin{array}{c}\text { C- } \\
\text { shaped, } \\
\text { Convex } \\
\text { lateral } \\
\text { surface* } \\
*\end{array}$ & $\begin{array}{c}\text { Bean } \\
\text { shaped* }\end{array}$ & \multirow{2}{*}{$\begin{array}{l}\text { 'V' or } \\
\text { heart- } \\
\text { shape } \\
\text { d }\end{array}$} & $\begin{array}{l}\text { J-or } \\
\text { Comma } \\
\text { shaped } \\
\quad *\end{array}$ & $\begin{array}{c}\text { Bean } \\
\text { Shaped* }\end{array}$ & $\begin{array}{c}\text { More } \\
\text { elongated } \\
\text { thin comma } \\
\text { shaped, }\end{array}$ & & \\
\hline & Left & & $\begin{array}{c}\text { C- } \\
\text { shaped } \\
\text { spheroid } \\
\text { al to } \\
\text { cylind- } \\
\text { rical } \\
\text { shape } \\
\end{array}$ & $\begin{array}{c}\text { Flattene } \\
\text { d, V- } \\
\text { shaped* } \\
*\end{array}$ & same & & $\begin{array}{l}\text { Tongue } \\
\text { shaped } \\
* *\end{array}$ & $\begin{array}{l}\text { Longer and } \\
\text { flatter than } \\
\text { right one* }\end{array}$ & $\begin{array}{l}\text { Like Peanut } \\
\text { shell } \\
\text { (dumbbell) }\end{array}$ & & \\
\hline \multirow{2}{*}{$\begin{array}{c}\text { Absolute } \\
\text { weight (g) }\end{array}$} & Right & 19.7 & 12-13* & $13-14^{*}$ & & \multirow[b]{2}{*}{0.83} & $28-56^{*}$ & 0.76-0.81* & $0.5^{*}$ & $0.5^{*}$ & \\
\hline & Left & $15-23$ & 14.5 & $15-16^{*}$ & & & same & $0.85-0.95^{*}$ & same & Same & \\
\hline \multirow{2}{*}{$\begin{array}{l}\text { Relative } \\
\text { weight \% }\end{array}$} & Right & & $\begin{array}{c}0.06- \\
0.09^{* *}\end{array}$ & $0.06^{* *}$ & & & & $0.004^{*}$ & & & \\
\hline & Left & & & & & & & $0.01^{*}$ & & & \\
\hline $\begin{array}{c}\text { Thicknesses } \\
\text { of zones of } \\
\text { adrenal } \\
\text { cortex }\end{array}$ & $\begin{array}{l}\text { ZG } \\
\mathrm{ZF} \\
\mathrm{ZR}\end{array}$ & & 294.52 & & & $\begin{array}{l}57.87 \\
62.08\end{array}$ & $\begin{array}{c}165 \\
2101 \\
2070\end{array}$ & & & & $\begin{array}{c}17 \\
79.65\end{array}$ \\
\hline $\begin{array}{l}\text { Diameter of } \\
\text { nuclei of zona } \\
\text { glomerulosa }\end{array}$ & & & & & & 6.46 & 5.27 & & & & \\
\hline $\begin{array}{l}\text { Mean volume } \\
\text { of nuclei of Z. } \\
\text { glomerulosa }\end{array}$ & & & 105.16 & & & 74.43 & 101.49 & & & & \\
\hline References & & $\begin{array}{c}\text { Rehan } \\
\text { and } \\
\text { Quresh } \\
\text { i, 2006, } \\
2007\end{array}$ & $\begin{array}{c}\text { Starke, } \\
\text { 1997[42 } \\
] \\
\text { Smollich } \\
1995^{* *}\end{array}$ & $\begin{array}{c}\text { Hussain } \\
\text { and } \\
\text { Qureshi, } \\
2007^{* *}\end{array}$ & $\begin{array}{c}\text { Erdoğan } \\
\text { and } \\
\text { Pérez, } \\
2014^{*}[4 \\
3]\end{array}$ & 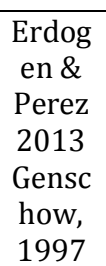 & $\begin{array}{l}\text { (Nican } \\
\text { der, } \\
(1952) \\
* *[44]\end{array}$ & $\begin{array}{l}\text { Saß, 1992, } \\
\text { Shah et al., } \\
2009^{*}[45] \\
\text { Qureshi et } \\
\text { al., 2013** }\end{array}$ & $\begin{array}{c}\text { (Harrison et } \\
\text { al., } \\
1966)^{*}[46]\end{array}$ & $\begin{array}{c}\text { (Harris } \\
\text { on } \text { et } \\
\text { al., } \\
1966)^{*}\end{array}$ & $\begin{array}{l}\text { Nietz,19 } \\
97\end{array}$ \\
\hline
\end{tabular}

Table3: Macroscopic and microscopic parameters of adrenal gland in different species.

Prasad and Sinha [41] found that the paired adrenal glands of goat were in proximity to the kidneys. The left adrenal was found anterior to the cranial pole of the left kidney and the right adrenal gland was found medial to the right kidney. Comparison of the anatomical shape and weight of the adrenal glands of various species has been given in (Table 3).

Many researchers worked on the morphological studies of these organs studied 100 pairs of normal adrenal glands in sheep of age 6 months to one year and 1-1.5 year. Significant difference was found between right and left adrenal gland, the mean length of left adrenal gland was greater than the right and the mean width of right was greater than left adrenal gland. It was conceivable from their findings that goat has a stable cardiovascular system. The development of adrenals showed an increase with advancing age to adjust with the increasing blood pressure due to morphological development process.

\section{Microscopic parameters of Adrenal Glands}

The adrenal glands of goat are composed of a capsule, a cortex, and a medulla. The zona fasciculate of the cortex was the thickest portion of the gland and was consistently thicker in females than in the males. Accessory adrenal 
cortical nodules occur in goat and might be located intracapsularly or extracapsularly. Extra capsular nodules were usually close to the adrenal glands [41]. In cattle zona glomerulosa was a narrow sub capsular cellular zone characterized by the presence of looped cords or thickness of cells which is approximately $350 \mu \mathrm{m}$ in thickness. In ruminants and horses, the cells of this zone were flattened to appear columnar in shape. In other domestic species, it tends to be polyhedral in outline. The zona fasciculata consisted of elongated inter anastomosing cords of polyhedral cells. This zone measured approximately $3 \mathrm{~mm}$ in adult cattle. The zona reticularis consisted of cells smaller but like those found in the zona fasciculata, the cells were arranged into a reticular pattern of irregular, inter anastomosing cords of cells.

\section{Discussion}

This paper mainly reviews the quantitative morphological data on the blood pressure and blood volume related organs i.e., heart, kidney and adrenal glands in various animal models for the better understanding of etiology and pathogenesis of heart related diseases.

\section{Heart}

Absolute and relative heart weight has a special standing due to direct with heart's pumping capacity while evaluating cardiovascular system. Cardiac ventricular weight is a variable of particular interest because it has been shown in human epidemiological studies that cardiac ventricular mass is one of the most important independent predictors of cardiovascular mortality and morbidity $[47,48]$. At the same time the landmarked clinical studies have proven that inhibition of the mechanism significantly decreases the morbidity and mortality from a wide-ranging spectrum of cardiovascular diseases including myocardial infarction, heart failure, coronary heart disease and diabetes. Roe-deer have a powerful heart, especially in relation to body and in comparison with other species. The very low of intramyocardial connective tissue is below that of the pygmy goat. The horse has the highest absolute heart weight, yet the relative weight is considerably higher in dogs.

\section{Kidney}

Kidneys play a significant role in maintaining of the normal blood pressure through regulation of water excretion. A change within a species is only possible by alteration in filtering surface of renal corpuscle. Besides this, renin-angiotensin-aldosteron mechanism (RAAS) plays an important role in the blood pressure regulation [49].

In Holstien-Fisien cattle the kidneys show larger cortical renal corpuscles compared to the juxtamedullary renal corpuscles in both sexes. The renal corpuscles volume in the cortical and juxtamedullary zone increase with age, the corpuscles density decrease in both zones. The distance of the first ten to the cortex renalis localized corpuscles, will be age related larger. Sex-related differences in the microscopic-anatomical kidney data are seldom proved. Mean subcapsular and juxtamedullary glomerular diameters in two species of cattle were reported as 197 and $175 \mu \mathrm{m}$ in Bos indicus and 194 and $201 \mu \mathrm{m}$ in Bos taurus, respectively [38]. Likewise, higher mean volumes of glomeruli of kidneys in young and adult buffaloes were documented. Significantly higher values of subcapsular glomerular volume, subcapsular and juxtamedullary glomerular surface area were reported in camel calves [18] as compared to teddy goats [20]. The reduced size of glomeruli in teddy goats may be due to their smaller size than other domestic animals.

\section{Adrenal Glands}

Structural morphology of zona glomerulosa of adrenals and the cell nucleus size of the endocrine cells also play very important role in cardiovascular system [50]. The increase in thickness of zones with age contributes to the increased weight and dimensions of adrenal glands in teddy goats as reported by [19]. These results are in line with the previous findings regarding the zona glomerulosa and zona fasiculata in sheep [51-56]. According to the trophic effect ACTH on the adrenal fasciculata might be the strongest determinant of changes in adrenal weight. Relatively higher values of mean diameter and volume of nuclei of zona glomerulosa cells of right and left adrenal glands were reported in camel calves Rehan and Qureshi [18] as compared to other species. A comparable trend with advancing age was recorded in sheep [51] and buffaloes. Sex had no significant effect on these two parameters. However, age induced a consistent rise in these parameters. The bulls show larger nuclei-volume of the zona glomerulosa cells, compared to the heifers [33]. 


\section{Effect of advancing age and sex}

The development of blood pressure regulating organs shows an increase in size analogous to the proceeding age to adjust with the increasing blood pressure due to growth and expansion process, however sex plays a secondary role.

Age induced a statistically significant rise in subcapsular and juxtamedullary glomerular diameter, surface area and volume in the right and left kidneys. However, relatively higher values of subcapsular glomerular were reported in goats. Gross- and microscopic- anatomical studies were performed on heart, kidney and adrenal gland of 55 Merino- sheep of various ages and sex. The adult animals in comparison to the juvenile had following variations of age on the studied organs: increase of the heart weight, increase of the nucleus size of the cardiomyocytes and of the endocrinocytes of the Zona glomerulosa, increase of the glomerular size and decrease of the glomerular density. There was no relationship between age and relative heart weight, the content of the intramyocardial connective tissue, the width of the Zona glomerulosa or the width of the Zona externa cortices renalis. The lambs showed sexspecific differences to following studied marks: smaller content of the intramyocardial connective tissue in the ventricular walls and a larger width of the Zona glomerulosa of the adrenal gland of the male animals than the female.

\section{Correlations}

Medium positive correlations were found between heart weight and volume of the myocytes nuclei as intramural content of the myocardial CT. Medium and strong positive correlations were found between the weights of the organs. Medium positive correlations were found between heart weight and volume of the myocytes nuclei as content of the myocardial CT. Medium negative correlations were found between heart weight and density of myocytes.

Medium positive correlations were found between kidney weight and size of glomeruli. In contrast, medium negative correlations were found between kidney weight and density of glomeruli. Medium positive correlations were found between adrenal gland weight and size of nuclei of the cells of $\mathrm{Z}$. glomerulosa. Medium negative correlations were found between adrenal gland weight and proportion of the adrenal gland cortex occupied by the $\mathrm{Z}$ glomerulosa in rabbits [13].

Anas SQ, et al. Functional Morphometric Research on Blood Regulating Organs in Animal Models with Special Emphasis on Cardiovascular Conditions: A Review. J Human Anat 2017, 1(1): 000102.
Medium negative and positive correlations were found between histological data of heart, kidney and adrenal gland. Between the microscopic-anatomical data numerous correlative relations are recorded. On the light microscopic level a slight indication is found to hormonal correlations between the intramyocardial connective tissue and the size of the cortical glomerulus. The correlation coefficient seems to reflect a cause-effect relation between hypertension as a result of the reninangiotensin-aldosteron-system and the microscopic anatomical structures.

\section{Conclusion}

Salient conclusion derived from the review of various studies on the qualitative and quantitative macroscopic and microscopic investigations on blood regulating organs in animal models with special emphasis on heart related diseases are given below:

1. Quantification and analysis of blood pressure regulating organs i.e., heart, kidneys and adrenal glands and its regional distribution provide vital information that is useful in investigating the pathophysiology of the cardiovascular diseases.

2. The development of blood pressure regulating organs glands shows an increase in size analogous to the proceeding age to adjust with the increasing blood pressure due to growth and expansion process, however sex plays a secondary role.

3. Race and sport animals including deer, horse dog and rabbit have a powerful heart, especially in relation to body and in comparison with other species.

4. Medium negative and positive correlations are found between histological data of heart, kidney and adrenal gland.

5. There are some correlations between some connective tissue parameters, which establish a morphophysiological relation with blood pressure regulating organs.

6. The correlation coefficient seems to reflect a causeeffect relation between hypertension as a result of the renin-angiotensin-aldosterone-system and the microscopic anatomical structures. Besides there is a slight indication to hormonal correlations between the intramyocardial connective tissue and the size of the cortical glomerulus. 


\section{References}

1. Watanabe S, Akita T, Itakura C, Goto M (1979) Evidence for a new letal gene causing cardiomyopathy in japanese black calves. J Hered 70(4): 255-258

2. Whittington RJ, Cook RW (1988) Cardiomyopathy and woolly haircoat syndrome of Poll Hereford cattle: electrocardiographic findings in affected. and unaffected calves. Austr Vet J 65 (11): 341-344

3. Storie GJ, Gibson JA, Taylor JD (1991) Cardiomyopathy and woolly haircoat syndrome of Hereford cattle. Aust Vet J 68 (3).

4. Wagner G (1997) Quantitativ-morphologische Untersuchungen an Herzen, Nieren und Nebennieren von normalen Kalbern unter besonderer Berueksichtigung des Geschlechts. Free University Berlin, Germany.

5. WHO (2016) Fact sheets - cardiovascular diseases. Global status report on noncommunicable diseases 2014.

6. Go AS, Chertow GM, Fan D, McCulloch CE , Hsu Cy (2004) Chronic kidney disease and the risks of death, cardiovascular events, and hospitalization. N Engl J Med 351: 1296-1305.

7. Cohn J (2007) Reducing cardiovascular risk by blockade of the reninangiotensin-aldosterone system. Adv Ther 24(6): 1290-1304.

8. Rao MS (2010) Inhibition of the renin angiotensin aldosterone system: focus on aliskiren. J Assoc Phys India 58: 102-108.

9. Shestakova MV (2011) Renin-angiotensin-aldosteron system: evolution of views from renin discovery to nowadays. Perspectives of therapeutic block. Ter Arkh 83(4): 71-77.

10. Funder JW, Reincke M (2010) Aldosterone: a cardiovascular risk factor? Biochim Biophys Acta 1802(12): 1188-1192.

11. Nappi JM, Sieg A (2011) Aldosterone and aldosterone receptor antagonists in patients with chronic heart failure. Vasc Health Risk Manag 7: 353-363.

Anas SQ, et al. Functional Morphometric Research on Blood Regulating Organs in Animal Models with Special Emphasis on Cardiovascular Conditions: A Review. J Human Anat 2017, 1(1): 000102.
12. Genschow A (1997) Makroskopisch- und mikroskopisch-anatomische Untersuchungen an Herz, Niere und Nebenniere des Rehes (Capreolus capreolus). Free University Berlin, Germany.

13. Nietz H (1997) Morphotnetrische Untersuchungenan Hen, Niere und Nebenniere von Kaninchen (Oryctolagus cuniculus f. domesticus) im Altersgang. Free University Berlin, Germany.

14. Pannwitz G (1997) Morphometrische Untersuchungenan Myokard, Niere Hnd Nebenniere von Puten der Masthybridlinie BIG-6 inter besonderer Berücksichtigung des intramyokardialen Bindegewebsgehaltes, der Kardiomyozyten und Analyse der Nierenglomeruli. Free University Berlin, Germany.

15. Hussain R, Qureshi AS, Shahid RU, Rahman SU (2006) Age related changes in the morphometric parameters of the heart, kidneys and adrenal glands of Nili-Ravi buffalo (Bubalus Bubalis). Pakistan Vet J 26(2): 59-62.

16. Hussain R, Qureshi AS (2006) Age related changes in the morphometric parameters of the Heart, Kidneys and Adrenal glands of Nili-Ravi buffalo (Bubalus bubalis). Pakistan Vet J 26(2): 59-62.

17. Rehan S, Qureshi AS (2006) Microscopic evaluation of the heart, Kidneys and adrenal glands of one-humped camel-calves (Camelus dromedarius) using semi automated image analysis system. Journal of Camel Practice and Research 13(2): 123-127.

18. Rehan S, Qureshi AS (2007) Microscopic evaluation of the heart, kidneys and adrenal glands of one-humped camel-calves using semi automated image analysis system. J Camel Prac Res 14: 27-31.

19. Shah M, Qureshi A, Rehan S, Hussain R (2010) Morphometric evaluation of blood pressure regulating organs in Teddy goats (Capra hircus) in relation to age and sex. Pak Vet J 30(1): 49-52.

20. Qureshi AS, Shah M, Rehan S, Pasha, RH, Ullah HA (2013) Histomorphometrical investigations on the heart, kidneys and adrenal glands in normal teddy goats (capra hircus) using image analysis system. Pak Vet J 33(2): 155-159.

21. Khan MS (2012) Macroscopic and microscopic studies on the heart, kidneys and adrenal glands in Dumbi sheep (Ovis aries). MPhil Anatomy. 
22. Frandson RD, Wilke WL, Fails AD (2009) Anatomy and physiology of farm animals. John Wiley \& Sons, USA.

23. Cope LA (2008) Dilated canine hearts: A specimen for teaching cardiac anatomy. Anat Sci Educ 1(5): 207211.

24. Dawson TJ, Webster KN, Mifsud B, Raad E, Lee E, Needham AD (2003) Functional capacities of marsupial hearts: size and mitochondrial parameters indicate higher aerobic capabilities than generally seen in placental mammals. J Comp Physiol B 173(7): 583-590.

25. Erickson H, Detweiler D, Reece W (2004) Regulation of the heart. Dukes' physiology of domestic animals 261-274.

26. Panhwar S, Perdehi M, Rind R, Sohoo MR (2004) Gross natomical studies on the heart of buffalo (Bubalis bubalis). Abstract book Nat'l Conf Agriand Anim Sci.

27. May ND (1970) The anatomy of the sheep: a dissection manual. University of Queensland press. Australia.

28. Smolich J (1995) Ultrastructural and functional features of the developing mammalian heart: a brief overview. Reproduction, Fertility and Development 7(3): 451-461.

29. Ghazi SR, Tadjalli M (1993) The anatomy of the atrioventricular bundle in the heart of camels (Camelus dromedarius). Vet Res Commun 179(6): 411-416.

30. Hamann F (1990) Korrelative morphologische Untersuchungen an Herz, Schilddrüse und Nebennieren von Schweinen der Rasse Leicoma.

31. Gunn HM (1989) Heart weight and running ability. J Anat 167: 225-233.

32. Núñez-Durán H (1981) Electron Microscopic Study of the Sarcolemma of Parkinje Cells of the Goat Heart. Acta Anat (Basel) 1099(1): 19-24.

33. Mischke A (1997) Makroskopisch- und mikroskopisch-anatomische Untersuchungen an Herz, Nieren und Nebennieren von normalgeschlachteten.

Anas SQ, et al. Functional Morphometric Research on Blood Regulating Organs in Animal Models with Special Emphasis on Cardiovascular Conditions: A Review. J Human Anat 2017, 1(1): 000102.
34. Spieler P (1995) Makroskopisch-und mikroskopisch, anatomische Untersuchungen an Herzen von normalen Bullen, Färsen und Kühen der Rasse Schwarzbuntes Milchrind unter besonderer Berücksichtigung des diffus verteilten, intramyokardialen Bindegewebes und der Kardiomyozytenkerne. Freie Universität Berlin.

35. El-Kammar M, Alsafy M, Mohammed M, Neweshy ElM (2012) Ureteric obstruction and hydronephrosis in baladi goats: Topographical anatomy, ultrasonographical, hematological and pathological findings. Small Ruminant Research 104(1-3): 169178.

36. Dyce KM, Sack WO, Wensing CJG (2009) Textbook of veterinary anatomy. Elsevier Health Sciences.

37. Zguigal $\mathrm{H}$, Ouhsine A (2004) Functional anatomy of the renal pelvis in the one humped camel. J Camel Sci 1: 81-85.

38. Mbassa G, Elger M, Kriz W (1988) The ultrastructural organization of the basement membrane of Bowman's capsule in the rat renal corpuscle. Cell and tissue res 253(1): 151-163.

39. Beeuwkes R, Bonventre JV (1975) Tubular organization and vascular tubular relations in the dog kidney. Am Am J Physiol 229(3): 695-713.

40. Gardiner DS, Downie I, Gibson IW, More IA, Lindop GB (1991) The glomerular peripolar cell: a review. Histol Histopathol 6(4): 567-73.

41. Prasad G, Sinha RD (1984) Comparative histology of adrenal zona glomerulosa in domestic animals. Indian J Animal Sci 54(3): 245-249.

42. Starke B (1997) Morphologische Untersuchungen an Herz, Niere und Nebenniere von Schafen unter besonderer Berücksichtigung des Blutdruckes. Free University Berlin.

43. Erdoğan S, Pérez W (2014) Arterial Vascularization and Morphological Characteristics of Adrenal Glands in the Pampas Deer (Ozotoceros bezoarticus, Linnaeus 1758). Anat Histol Embryol 43(5): 369-374.

44. Nicander L (1952) Histological and histochemical studies on the adrenal cortex of domestic and laboratory animals. Acta Anat. 14(16): 1-88. 
45. Saß T (1992) Die Altersentwicklung des Bindegewebsanteils, der Nichtmyozyten und Myozyten im Ventrikelmyokard der Zwergziege. Vet med Diss Berlin, Germany.

46. Harrison FA, McDonald IR (1966) The arterial supply to the adrenal gland of the sheep. J Anat 100: 189202.

47. Levy D, Garrison RJ, Savage DD, Kannel WB, Castelli WP (1990) Prognostic implications of echocardiographically determined left ventricular mass in the Framingham heart study. $\mathrm{N}$ Engl J Med 322(22): 1561-1566.

48. De Simone G, P Verdecchia, Pede S, Gorini M, Maggion AP (2002) Prognosis of inappropriate left ventricular mass in hypertension. Hypertension 40(4): 470-476.

49. Saavedra JM, Viswanathan M, Shigematsu K (1993) Localization of angiotensin AT 1 receptors in the rat heart conduction system. European journal of pharmacology 235(2-3): 301-303.

50. Shah M, Qureshi AS, Rehan S, Hussain R (2010) Morphometric evaluation of blood pressure regulating organs in teddy goats (Capra hircus) in relation to age and sex. Pak Vet J 30(1): 49-52.
51. Tiwari GP, Swarup H (1977) Histology of the nephron of kidney of the Indian buffalo. Indian J Anim Sci 47: 79-84.

52. Deschepper CF, Olson JL, Otis M, Gallo Payet N (2004) Characterization of blood pressure and morphological traits in cardiovascular-related organs in 13 different inbred mouse strains. J Appl Physiol 97(1): 369-376.

53. Bullen und Färsen der Rasse Holstein-Friesian. Free University Berlin. Germany

54. Koch T, Berg R (1993) Lehrbuch der VeterinärAnatomie Band III Gustav Fischer Verlag Jena/ Stuttgart, 5. Auflage.

55. Qureshi A, Hussain R (2010) Morphometric evaluation of the blood pressure related organs in nili-ravi buffalo (bubalus bubalis) with advancing age. Italian Journal of Animal Science 6(2): 961-964.

56. Smolich JJ, Shimada T, Canale E, Campbell GR (1990) Developmental morphology of vascular and lymphatic capillaries in the working myocardium and Purkinje bundle of the sheep septomarginal band. Anat Rec 226(1): 48-56. 